\title{
Oxidative stability of cereal bars made with fruit peels and baru nuts packaged in different types of packaging
}

\author{
Nathalia da Silva Rodrigues MENDES ${ }^{1}$, Cristiane Rodrigues GOMES-RUFFI ${ }^{2}$, \\ Moacir Evandro LAGE ${ }^{3}$, Fernanda Salamoni BECKER ${ }^{1}$, Adriane Alexandre Machado de MELO ${ }^{1}$, \\ Flávio Alves da SILVA ${ }^{1}$, Clarissa DAMIANI ${ }^{4 *}$
}

\begin{abstract}
Food industries have been concerned about managing the waste generated by their production processes in order to minimize environmental impacts and also about the development of formulations with different and innovative ingredients such as fruits from the Brazilian savanna. Seeking to meet the expectations of consumers who desire healthy and practical products, this study aimed to evaluate the oxidative stability and the variations in chemical composition and antioxidant potential of cereal bars made with fruit peels and baru nuts packaged in different types of packaging. The bars formulated were packed in four different types of packaging: laminated without vacuum (LWV), transparent without vacuum (TWV), transparent under vacuum (TV), and laminated under vacuum (LV); they were subsequently analyzed for proximate composition, fatty acid profiles, antioxidant activity, and oxidative capacity. The results showed that the cereal bars made with fruit peel and baru are sources of protein, dietary fiber, and fat, especially unsaturated fatty acids such as oleic and linoleic acids. The cereal bars exhibited oxidative stability up to 120 days of storage, and the type of packaging was not significant for the variables evaluated; therefore, they can be stored in low cost packaging such as transparent packaging without vacuum for a period of 120 days.
\end{abstract}

Keywords: waste recovery; savanna; oxidation.

\section{Introduction}

Changes in lifestyle and dietary habits of individuals may affect nutrient intake and nutritional requirements; therefore, a healthy and balanced diet is important to meet the basic needs of human body. Accordingly, cereal bars are among the most sophisticated ready-to-eat products due to their natural ingredients and the fact they are healthy (GRDEN; OLIVEIRA; BORTOLOZO, 2008).

The processing of bars occur in two stages: solid phase, compaction of grains (cereals and fabaceaes), nuts (cashews and almonds), and dried fruits in a variety of combinations; continuous phase, addition of binding substances such as honey, molasses, brown sugar, sucrose, glucose syrup, invert sugar, soy lecithin, glycerin, citrus pectin, oils, vegetable fat and others (DE PAIVA, 2008).

In addition to meeting consumer needs for healthier products in recent years, special attention has been given to minimize or reuse solid waste generated in various industrial processes, thus avoiding the loss of remaining substances, economic losses, and environmental pollution. Furthermore, a major concern in the food industry today is the proper management or the minimization of waste generated in industrial processes.
Therefore, several Brazilian researchers have been studying the use of wastes such as fruit peels generated by agro-industries in the production of foods or ingredients. Another area that also arouses the interest from researchers is the development of new products with the use of fruits from the Brazilian savanna. Baru is among the many fruits from the Brazilian savanna, whose raw or roasted nuts are greatly appreciated by the local population.

Cereal bars with the addition of fruit peels and baru nuts can provide important supplemental calories and nutrients such as lipids, fiber, protein, minerals, and vitamins. Due to their considerable content of lipids and large amounts of polyunsaturated fatty acids, they are susceptible to oxidative deterioration, which reduces stability during storage. The oxidative rancidity of fats may result in the development of toxic products, changes in color and texture, and loss of nutritional value due to the destruction of vitamins and essential fatty acids. Oxidation is catalyzed by a number of factors such as oxygen, light, heat, metals, pigments, alkaline conditions, and degree of instauration of fats; therefore, studies should be carried out in order to reduce these effects (CHAIYASIT et al., 2007).

Removal of oxygen, inactivation of enzymes, and protection from light and metal ions are important measures to avoid or minimize lipid oxidation; nevertheless, these measures are not frequently applied. The most common method to increase the

\section{Received 8/15/2012}

Accepted 9/23/2013 (005856)

1 Department of Food Engineering, School of Agronomy and Food Engineering, Federal University of Goias - UFG, Goiânia, GO, Brazil

2 Department of Food Supply of the State of São Paulo, Institute of Food Technology, Agriculture, Centre for Cereal and Chocolate Technology, Campinas, SP, Brasil

${ }^{3}$ School of Veterinary, Federal University of Goias - UFG, Goiânia, GO, Brazil

${ }^{4}$ Department of Food Engineering, School of Agronomy and Food Engineering, Federal University of Goias - UFG, Rod. Goiânia, Km 0, Nova Veneza,

CEP 74001-970, Goiânia, GO, Brazil, e-mail: damianiclarissa@hotmail.com

${ }^{*}$ Corresponding author 
stability of lipids is the addition of antioxidants (DECKER; XU, 1999), which can be added to cereal bars by using fruit peels.

Vegetable materials contain many compounds with antioxidant activity. Several plants have been studied for being potentially safe natural antioxidants for the food industry; various compounds have been isolated, such as polyphenols. A wide range of low and high molecular weight plant polyphenolics with antioxidant properties has been studied and suggested for its protectitive effect against lipid oxidation (MOURE et al., 2001).

Apple and papaya fruits have been shown to be a good source of polyphenols which are predominantly localized in the peels (FALLER; FIALHO, 2010). Apple peels have higher contents of phenolic compounds when compared to those of other edible parts of the apple (SCHIEBER; STINTZING; CARLE, 2001; WOLFE; WU; LIU, 2003) and the pulp and peel of organic papaya had approximately $70 \%$ higher hydrolysable polyphenols when compared to those of papaya pulp (FALLER; FIALHO, 2010).

Therefore, the objective of this study was to evaluate the oxidative stability and variations in chemical composition and antioxidant potential of cereal bars developed with fruit peels and baru nuts packaged in different types of packaging.

\section{Materials and methods}

\subsection{Materials}

The ingredients used in the preparation of the cereal bars made with fruit peels and baru nuts were: soy lecithin (Lecsam L, Bunge Alimentos S/A, Esteio, Brazil), glucose syrup (Glucogil 40/82, Cargill, Guarujá, Brazil), vegetable fat (Liza, Cargill, Uberlândia, Brazil), salt (Cisne, Refinaria Nacional de Sal S.A, Cabo Frio, Brazil), commercial sucrose (Cristal, Cristal Alimentos Ltda, Aparecida de Goiânia, Brazil), acacia gum (Fibregum, Nexira, São Paulo, Brazil), rice flakes (Harald Confeiteiro, Harald Indústria e Comércio de Alimentos Ltda, Jundiaí, Brazil), and oat (Quaker, PepsiCo, Porto Alegre, Brazil). The roasted baru nuts, apple, and papaya were obtained from a local market.

\subsection{Cereal bar processing}

The cereal bars were developed at the Institute of Food Technology (ITAL), Campinas/SP, through laboratory tests to define the standard formulation shown in Table 1. Their formulation was composed of dry ingredients (apple and papaya peels dried at $80^{\circ} \mathrm{C}$ in stove for 6 hours; roasted baru nuts, rice flakes, and oat) and binders (soy lecithin, glucose syrup, vegetable fat, salt, water, commercial sucrose, and acacia gum) (Table 1). The dry ingredients and binders were homogenized separately, and these binders were combined and mixed until forming syrup liquid, when the dry ingredients were added.

The mass obtained was placed in the laminating table and, after cooling, they were cut uniformly into $30 \mathrm{~g}$, pieces using a dough scraper. Three batches of $1000 \mathrm{~g}$ of cereal bars were produced, and the standardized bars were $9 \mathrm{~cm}$ long, $3 \mathrm{~cm}$ wide,
Table 1. Formulation of cereal bars made with fruit peels and baru nuts.

\begin{tabular}{cc}
\hline Ingredients & Amount (\%) \\
\hline Roasted baru nuts & 20.00 \\
Dry fruit peels (apple and papaya) & 14.00 \\
Rice flakes & 9.00 \\
Oat & 7.30 \\
Salt & 0.20 \\
Commercial sucrose & 2.50 \\
Soy lecithin & 1.00 \\
Glucose syrup & 31.00 \\
Vegetal fat & 3.00 \\
Water & 7.00 \\
Acacia gum & 5.00 \\
\hline
\end{tabular}

and $1 \mathrm{~cm}$ thick. The bars were packed under and without vaccum (300 B, Selovac', São Paulo, Brazil) in four different types of plastic laminates (treatments), PET/Polyethylene with density of $100 \mathrm{~g} / \mathrm{m}^{2}$ : laminated without vacuum (LWV), transparent without vacuum (TWV), transparent under vacuum (TV), and laminated under vacuum (LV); they were labeled and stored at room temperature in a cool and dry environment.

\subsection{Chemical analyses}

Chemical analyses were performed at the Physiochemical laboratory, Department of Food Engineering, School of Agronomy and Food Engineering, Chemistry and Biochemistry of Foods, Faculty of Pharmacy and Research Center in Foods - CPA, School of Veterinary Medicine, both located at the Federal University of Goiás - UFG. The samples were randomly collected for analysis.

Lipid oxidation was monitored by the analyses of the oxidative capacity (TBA), antioxidant activity (DPPH), and fatty acid profile, which were performed at $0\left(\mathrm{t}_{0}\right), 30\left(\mathrm{t}_{1}\right), 60\left(\mathrm{t}_{2}\right), 90$ $\left(t_{3}\right)$, and $120\left(t_{4}\right)$ days of storage. Proximate composition and dietary fiber were determined at the beginning $\left(\mathrm{t}_{0}\right)$ and at 120 days $\left(t_{4}\right)$ of storage. The chemical analyses were performed up to the fourth month of storage (120 days) because the cereal bar made with fruit peels and baru nuts did not show oxidative stability thereafter.

Lipid oxidation was determined by the TBA test according to Tarladgis, Pearson and Jun (1964) and fatty acids profile according to Joseph and Ackman (1992), both performed in triplicate. The scavenging capacity was determined by the $\mathrm{DPPH} \bullet$ method (2,2-diphenyl-1-picrylhydrazyl) in triplicate, according to Brand-Williams, Cuvelier and Berset (1995) and modified by Borguini (2006). Butylated hydroxytoluene (BHT) was used as the standard substance antioxidant.

The proximate composition was also determined in triplicate: stove moisture at $105^{\circ} \mathrm{C}$ until a constant weight was reached, total nitrogen was converted to total crude protein according to the Kjeldahl method using a nitrogen conversion factor of 6.25; ash was determined by incineration in a muffle furnace at $550^{\circ} \mathrm{C}$, soluble and insoluble dietary fiber by enzymatic gravimetric method (ASSOCIATION..., 1997), lipids 
by the method of Bligh and Dyer (1959), total carbohydrates by difference as suggested by FAO (FOOD..., 2003), and total energy value according to Brasil (2003).

After analysis of variance (ANOVA), when significant, the means were compared using the Tukey test (5\% probability) and the SISVAR 5.3 statistical package (FERREIRA, 2000). Polynomial regression models were selected based on the significance of the $\mathrm{F}$ test for each model tested and also by the determination coefficient.

\section{Results and discussion}

\subsection{Proximate composition}

The proximate composition results expressed on a wet basis and total energy value of cereal bar made with fruit peels and baru are shown in Table 2.

As can be seen in Table 2, all cereal bars packed in LWV, TWV, TV, and LV packaging showed no significant difference ( $\mathrm{p}>$ 0.05 ) between $\mathrm{t}_{0}$ and $\mathrm{t}_{4}$ when proximate composition parameters (moisture content, ash, lipids, proteins, carbohydrates) and total energy values were evaluated individually. However, a significant difference $(\mathrm{p}<0.05)$ was observed for total soluble and insoluble fibers when the treatments were analyzed individually and in the interaction treatment $v s$ storage time .However, when evaluating storage time alone, a significant difference $(\mathrm{p}<0.05)$ was observed for the variables lipids, ash, total carbohydrates, soluble fiber, and total energy. There was a decrease in ash, lipids, and total energy and an increase in total carbohydrates; variable soluble fibers showed increased levels in LWV and LV packaging, while in TWV and TV packaging, they decreased the analyses at 0 and 120 days of storage.

The differences in the variables studied may be due to the heterogeneous structure of cereal bars, which may show different amounts of ingredients, especially those with large particle size such as fruit peels and baru nuts. Freitas and Moretti (2005) studied the stability of cereal bars with high protein and vitamin content and found that the manufacturing process of cereal bars may cause these differences since these products exhibit variability from sample to sample and from batch to batch.

The average moisture content obtained for cereal bars made with fruit peel and baru submitted to the four treatments was 11.99 g. $100 \mathrm{~g}^{-1}$, which corroborate the values found by Lima et al. (2010), who found moisture contents ranging from

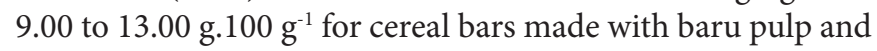
almond.

In a study on the stability of cereal bars with high protein and vitamin levels using three packaging films (PET/PEBD; PETmet/PEBD and PET/PEBD/AL/PEBD) with different barrier properties and stored at room temperature and standard relative humidity for a period of 180 days, Freitas and Moretti (2005) observed that the moisture content of cereal bars tended to increase, and they also found that the best packaging was the one containing aluminum in its composition. The moisture contents ranged from 10.19 to $12.37 \mathrm{~g} .100 \mathrm{~g}^{-1}$, which are in agreement with the values found in the present study; however,
Table 2. Proximate composition levels (wet basis) of cereal bars made with fruit peels and baru at the beginning $\left(\mathrm{t}_{0}\right)$ and 120 days $\left(\mathrm{t}_{4}\right)$ of storage.

\begin{tabular}{|c|c|c|c|}
\hline \multirow{2}{*}{ Parameter } & \multirow{2}{*}{ Treatment $^{1}$} & \multicolumn{2}{|c|}{ Time $^{2}$} \\
\hline & & 0 days & 120 days \\
\hline \multirow{4}{*}{$\begin{array}{l}\text { Moisture } \\
\left(\text { g. } 100 \mathrm{~g}^{-1}\right)\end{array}$} & LWV & $11.85^{\mathrm{Aa}} \pm 0.11$ & $11.76^{\mathrm{Aa}} \pm 0.24$ \\
\hline & TWV & $11.85^{\mathrm{Aa}} \pm 0.11$ & $11.98^{\mathrm{Aa}} \pm 0.95$ \\
\hline & TV & $11.85^{\mathrm{Aa}} \pm 0.11$ & $12.21^{\mathrm{Aa}} \pm 0.53$ \\
\hline & LV & $11.85^{\mathrm{Aa}} \pm 0.11$ & $12.17^{\mathrm{Aa}} \pm 0.70$ \\
\hline \multirow{4}{*}{$\begin{array}{c}\text { Ash } \\
\left(\mathrm{g} .100 \mathrm{~g}^{-1}\right)\end{array}$} & LWV & $2.09^{\mathrm{Aa}} \pm 0.01$ & $1.94^{\mathrm{Ab}} \pm 0.11$ \\
\hline & TWV & $2.09^{\mathrm{Aa}} \pm 0.01$ & $1.89^{\mathrm{Ab}} \pm 0.12$ \\
\hline & TV & $2.09^{\mathrm{Aa}} \pm 0.01$ & $1.76^{\mathrm{Ab}} \pm 0.26$ \\
\hline & LV & $2.09^{\mathrm{Aa}} \pm 0.01$ & $1.90^{\mathrm{Ab}} \pm 0.13$ \\
\hline \multirow{4}{*}{$\begin{array}{l}\text { Proteins } \\
\left(\mathrm{g} .100 \mathrm{~g}^{-1}\right)\end{array}$} & LWV & $9.91^{\mathrm{Aa}} \pm 0.15$ & $9.50^{\mathrm{Aa}} \pm 0.21$ \\
\hline & TWV & $9.91^{\mathrm{Aa}} \pm 0.15$ & $9.62^{\mathrm{Aa}} \pm 0.62$ \\
\hline & TV & $9.91^{\mathrm{Aa}} \pm 0.15$ & $10.08^{\mathrm{Aa}} \pm 0.82$ \\
\hline & LV & $9.91^{\mathrm{Aa}} \pm 0.15$ & $9.91^{\mathrm{Aa}} \pm 0.92$ \\
\hline \multirow{4}{*}{$\begin{array}{l}\text { Lipids } \\
\left(\mathrm{g} .100 \mathrm{~g}^{-1}\right)\end{array}$} & LWV & $14.55^{\mathrm{Aa}} \pm 0.25$ & $13.11^{\mathrm{Ab}} \pm 0.41$ \\
\hline & TWV & $14.55^{\mathrm{Aa}} \pm 0.25$ & $12.46^{\mathrm{Ab} \pm} 0.69$ \\
\hline & TV & $14.55^{\mathrm{Aa}} \pm 0.25$ & $13.47^{\mathrm{Ab}} \pm 0.19$ \\
\hline & LV & $14.55^{\mathrm{Aa}} \pm 0.25$ & $13.10^{\mathrm{Ab}} \pm 0.40$ \\
\hline \multirow{4}{*}{$\begin{array}{l}\text { Carbohydrates } \\
\quad\left(\text { g. } 100 \mathrm{~g}^{-1}\right)\end{array}$} & LWV & $61.61^{\mathrm{Aa}} \pm 0.46$ & $63.69^{\mathrm{Ab}} \pm 0.90$ \\
\hline & TWV & $61.61^{\mathrm{Aa}} \pm 0.46$ & $64.05^{\mathrm{Ab}} \pm 1.28$ \\
\hline & TV & $61.61^{\mathrm{Aa}} \pm 0.46$ & $62.48^{\mathrm{Ab}} \pm 1.01$ \\
\hline & LV & $61.61^{\mathrm{Aa}} \pm 0.46$ & $62.92^{\mathrm{Ab}} \pm 0.41$ \\
\hline \multirow{4}{*}{$\begin{array}{l}\text { Total fibers } \\
\left(\mathrm{g} .100 \mathrm{~g}^{-1}\right)\end{array}$} & LWV & $18.13^{\mathrm{Aa}} \pm 0.80$ & $19.30^{\mathrm{Aa}} \pm 0.26$ \\
\hline & TWV & $18.13^{\mathrm{Aa}} \pm 0.80$ & $16.93^{\mathrm{Ba}} \pm 0.80$ \\
\hline & TV & $18.13^{\mathrm{Aa}} \pm 0.80$ & $16.80^{\mathrm{Ba}} \pm 0.00$ \\
\hline & LV & $18.13^{\mathrm{Aa}} \pm 0.80$ & $20.00^{\mathrm{Aa}} \pm 0.75$ \\
\hline \multirow{4}{*}{$\begin{array}{l}\text { Soluble fibers } \\
\quad\left(\mathrm{g} .100 \mathrm{~g}^{-1}\right)\end{array}$} & LWV & $9.16^{\mathrm{Aa}} \pm 0.45$ & $10.70^{\mathrm{Ab}} \pm 0.46$ \\
\hline & TWV & $9.16^{\mathrm{Aa}} \pm 0.45$ & $8.67^{\mathrm{Bb}} \pm 0.42$ \\
\hline & TV & $9.16^{\mathrm{Aa}} \pm 0.45$ & $8.43^{\mathrm{Bb}} \pm 0.15$ \\
\hline & LV & $9.16^{\mathrm{Aa}} \pm 0.45$ & $10.50^{\mathrm{Ab}} \pm 0.43$ \\
\hline \multirow{4}{*}{$\begin{array}{l}\text { Insoluble fibers } \\
\quad\left(\mathrm{g} .100 \mathrm{~g}^{-1}\right)\end{array}$} & LWV & $8.97^{\mathrm{Aa}} \pm 0.35$ & $8.60^{\mathrm{Aa}} \pm 0.20$ \\
\hline & TWV & $8.97^{\mathrm{Aa}} \pm 0.35$ & $8.27^{\mathrm{Aa}} \pm 0.40$ \\
\hline & TV & $8.97^{\mathrm{Aa}} \pm 0.35$ & $8.37^{\mathrm{Aa}} \pm 0.15$ \\
\hline & LV & $8.97^{\mathrm{Aa}} \pm 0.35$ & $9.50^{\mathrm{Ba}} \pm 0.44$ \\
\hline \multirow{4}{*}{$\begin{array}{l}\text { Energy value } \\
\left(K_{c a l} 100 g^{-1}\right)\end{array}$} & LWV & $416.99^{\mathrm{Aa} \pm} 1.08$ & $410.73^{\mathrm{Ab} \pm} 1.02$ \\
\hline & TWV & $416.99^{\mathrm{Aa} \pm} 1.08$ & $406.83^{\mathrm{Ab} \pm} 1.54$ \\
\hline & TV & $416.99^{\mathrm{Aa} \pm} 1.08$ & $411.45^{\mathrm{Ab} \pm} 2.72$ \\
\hline & LV & $416.99^{\mathrm{Aa} \pm} 1.08$ & $409.23^{\mathrm{Ab} \pm} 4.18$ \\
\hline
\end{tabular}

${ }^{1} \mathrm{LWV}=$ laminated without vacuum; TWV $=$ transparent without vacuum; $\mathrm{TV}=$ transparent under vacuum; $\mathrm{LV}=$ laminated under vacuum. ${ }^{2}$ Values are expressed as mean \pm standard deviation of three replicates. Means followed by same uppercase in the same column and lowercase in the same line are not different from each other by the Tukey test at $5 \%$ probability.

packaging type was not a significant factor $(\mathrm{p}<0.05)$ under the same storage conditions. Therefore, in the present study, moisture content and type of packaging used promoted stable storage without causing major changes in the quality of the product for a period of 120 days.

The ash content changed over the storage time, but it is in agreement with results obtained by Carvalho (2008), who developed cereal bars made with Sterculia striata St. Hill. et Naud, Lecythis pisonis Camb., and Dipteryx lacunifera Ducke with 
the addition of pineapple peel in three different formulations obtaining ash contents ranging from 1.80 to $2.30 \mathrm{~g} .100 \mathrm{~g}^{-1}$.

Ash content is related to the mineral content of the formulation ingredients, and these results are due to nuts, which can be considered source of minerals, especially calcium, iron and zinc, as reported by Fernandes et al. (2010) and Lima et al. (2010), who characterized baru almond and found ash content of $3.03 \mathrm{~g} .100 \mathrm{~g}^{-1}$. According to Cecchi (2003), cereals have total

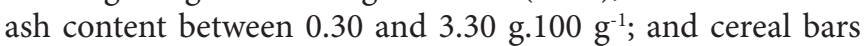
made with fruit peel and baru show significant ash content, contributing to the supply of minerals in the diet.

The lipid levels were higher than those of cereal bars added of dried murici, 4.70 g. $100 \mathrm{~g}^{-1}$ (GUIMARÃES; SILVA, 2009) and than cereal bars made with baru pulp and almond in three different formulations, whose contents ranged from 10.48 to $11.06 \mathrm{~g}^{1} 100 \mathrm{~g}^{-1}$ (LIMA et al., 2010). The high lipid content of the cereal bars formulated in the present study is due to the addition of baru nuts, which has a lipid content of $40.98 \mathrm{~g} .100$ $\mathrm{g}^{-1}$, according to a study by Lima et al. (2010).

The protein content of cereal bars made with fruit peel and baru were higher than that of cereal bars made with dried banana and dried murici, according to Guimarães and Silva (2009), which ranged from $6.90 \mathrm{~g} .100 \mathrm{~g}^{-1}$ to $7.70 \mathrm{~g} .100 \mathrm{~g}^{-1}$, but they were similar to the values reported by Gutkoski et al. (2007), from $9.79 \mathrm{~g} .100 \mathrm{~g}^{-1}$ to $12.37 \mathrm{~g} .100 \mathrm{~g}^{-1}$ for cereal bars made with oats, and by Lima et al. (2010) for cereal bars made with baru almond and pulp (10.23 to $11.23 \mathrm{~g} .100 \mathrm{~g}^{-1}$ ). The high protein content found in this study results from the addition of baru almond, which has good digestibility (80\%) and good amino acid profile meeting $92 \%$ of essential amino acid requirements recommended for school children, according to Fernandes et al. (2010).

The high contents of total carbohydrates found in the cereal bars made with fruit peel and baru are in agreement with those found by Freitas and Moretti (2006) in cereal bars made

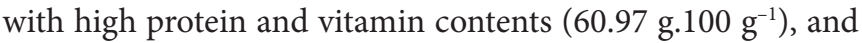
with those found by Carvalho (2008) in cereal bars made with Lecythis pisonis Camb. almond (63.90 g. $100 \mathrm{~g}^{-1}$ ); however, they are lower than the levels obtained by the same author for cereal bars made with Dipteryx lacunifera Ducke and Sterculia striata St. Hill. et Naud, 69.30 and 70.70 g. $100 \mathrm{~g}^{-1}$, respectively. The high contents of total carbohydrates are due to the addition of cereals (rice and oat flakes) and sugar in the formulation of cereal bars.

The levels of total soluble and insoluble dietary fiber found in the cereal bars made with fruit peels and baru were similar to the levels found in cereal bars made with baru almond and pulp, which ranged from 14.86 to $16.73 \mathrm{~g} .100 \mathrm{~g}^{-1}$ for total dietary fiber, from 2.13 to $6.33 \mathrm{~g} .100 \mathrm{~g}^{-1}$ for soluble fibers, and from 10.40 to $12.70 \mathrm{~g} .100 \mathrm{~g}^{-1}$ for insoluble fibers (LIMA et al. 2010); nevertheless, they were higher than the levels found for bars made with industrial passion fruit waste (SILVA et al., 2009) and those fortified with iron (SAMPAIO; FERREIRA; CANNIATTIBRAZACA, 2010), which showed total dietary fiber content of

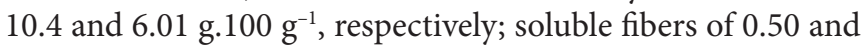
$2.93 \mathrm{~g} .100 \mathrm{~g}^{-1}$, respectively; and insoluble fibers of 9.80 and 3.08 g. $100 \mathrm{~g}^{-1}$, respectively.
Thus, the cereal bars formulated in the present study may be classified as source of dietary fiber, according to the RDC resolution No. 360 of December 23, 2003, which recommends a minimum of $6.00 \mathrm{~g}$ of fibers per $100 \mathrm{~g}$ of solid product to be considered rich in fiber (BRASIL, 2003). Therefore, it can be inferred that the high concentration of dietary fiber found in these products is due to the addition of baru almonds, to the content of total, soluble, and insoluble fractions, $14.26 \mathrm{~g} .100$ $\mathrm{g}^{-1}, 13.35 \mathrm{~g} .100 \mathrm{~g}^{-1}$, and $0.90 \mathrm{~g} .100 \mathrm{~g}^{-1}$, respectively (according to Lima et al. (2010)); to the addition of oat, $10.39 \mathrm{~g} .100 \mathrm{~g}^{-1}$, $7.78 \mathrm{~g} .100 \mathrm{~g}^{-1}$, and $2.61 \mathrm{~g} .100 \mathrm{~g}^{-1}$ of total, insoluble, and soluble dietary fiber, respectively (according to Freitas and Moretti (2005)); and also to the fruit peels included in the formulation.

The energy value of the product formulated was higher than that found by Lima et al. (2010) for cereal bars made with baru almond and pulp (337.37 kcal.100 g $\mathrm{g}^{-1}$ ), and cereal bars made with macauba nuts ( $\left.348.66 \mathrm{kcal} 100 \mathrm{~g}^{-1}\right)$, but they energy levels had similar to those found in study carried out by Carvalho (2008) on cereal bars made with Sterculia striata St. Hill. et Naud, Lecythis pisonis Camb., and Dipteryx lacunifera Ducke nuts added with with the addition of pineapple peel, whose levels ranged from 407.50 to $434.00 \mathrm{kcal} .100 \mathrm{~g}^{-1}$.

Although there are some differences in the chemical composition of the cereal bars, the changes in terms of nutritional quality were not relevant during the 120 days of storage. Thus, type of packaging was not a factor that caused changes in the proximate composition of cereal bars made with fruit peel and baru stored for a period of 120 days; therefore, the transparent packaging without vacuum and that laminated under vacuum can be used.

\subsection{Antioxidant activity and oxidative capacity}

Cereal bars made with fruit peel and baru packaged in LWV, TWV, TV, and LV types of packaging showed antioxidant potential only at 0 time $\left(\mathrm{t}_{0}\right)$, as shown in Table 3.

The degree of discoloration (\% RSC, Radical Scavenging Capacity) indicates the antioxidant potential of the extract. An extract showing high capacity to scavenge free radicals have low $\mathrm{IC}_{50}$ value (concentration index), i.e., the amount of extract capable of decreasing the initial DPPH radical concentration by $50 \%$ or even of inhibiting the radical oxidation by $50 \%$. The ethereal, alcoholic and aqueous extracts of the cereal bars showed low scavenging activity by the DPPH free radical method, when compared with standard antioxidant BHT and with \% DSC of the conventional tomato's ethereal extract (BORGUINI, 2006).

The $\mathrm{IC}_{50}$ of all extracts of the cereal bars evaluated showed higher values than the indices of alcoholic and aqueous extracts of the peels of pequi, lobeira and araticum; except for the $\mathrm{IC}_{50}$ of the aqueous extract of lobeira's peel, which showed $\mathrm{IC}_{50}$ as high as that of the cereal bars' aqueous extract (ROESLER et al., 2007). Thus, a large volume of the extracts obtained from cereal bar is required to decrease the initial concentration of the radical $\mathrm{DPPH}$ in 50\%, indicating a low antioxidant capacity of the cereal bars with fruit peel and baru nuts. 
Table 3. Average antioxidant potential of cereal bars made with fruit peel and baru nuts at the beginning $\left(\mathrm{t}_{0}\right)$ of storage.

\begin{tabular}{|c|c|c|c|c|c|c|}
\hline \multirow{3}{*}{ Extract } & \multirow{2}{*}{$\begin{array}{c}\text { Conventional } \\
\text { Tomato }^{2} \\
\end{array}$} & \multirow{2}{*}{\multicolumn{2}{|c|}{ Cereal Bar }} & \multicolumn{3}{|c|}{$\mathrm{Peel}^{3}$} \\
\hline & & & & Pequi & Lobeira & Araticum \\
\hline & \multicolumn{2}{|c|}{$\% \mathrm{RSC}^{1}$} & & \multicolumn{2}{|c|}{$\mathrm{IC}_{50}\left(\mu \mathrm{g} \cdot \mathrm{mL}^{-1}\right)$} & \\
\hline Ethereal & $59.59-72.04$ & $14.71 \pm 0.40$ & $680.21 \pm 2.79$ & - & - & - \\
\hline Aqueous & $10.47-12.19$ & $8.79 \pm 1.29$ & $1148.39 \pm 0.04$ & $17.98 \pm 0.35$ & $1328.98 \pm 9.42$ & $198.28 \pm 8.24$ \\
\hline Standard & - & $97.35 \pm 1.81$ & $14.69 \pm 1.39$ & $1.38 \pm 0.01$ & $1.38 \pm 0.01$ & $1.38 \pm 0.01$ \\
\hline
\end{tabular}

${ }^{1}$ RSC = Radical scavenging capacity $(\mathrm{DPPH}) .{ }^{2}$ Alcoholic extract $=5: 95$, v.v ${ }^{-1}$, water:ethanol; Standard $=$ gallic acid $($ ROESLER et al., 2007).

${ }^{3}$ Alcoholic extract $=$ ethanol; Ethereal extract $=$ ethyl ether (BORGUINI, 2006).

Although low, the antioxidant capacity of these cereal bars is associated with its ingredients since studies have shown the existence of phenolic compounds of antioxidant action in apple and papaya peels and baru almond (FALLER; FIALHO, 2010; FREITAS; NAVES, 2010; NOGUEIRA et al., 2003), which are ingredients used in the formulation of the cereal bars evaluated. Apple and papaya peels of conventional fruits showed 93.10 and $76.70 \%$ RDC (\% radical scavenging capacity, DPPH, 80\% methanol); but, in organic fruits they were 79.60 and $89.90 \%$ RDC, respectively (FALLER; FIALHO, 2010).

The dehydration of papaya and apple peels and the use of the roasted baru nuts may have contributed to the reduction in the antioxidant capacity of these components in the cereal bars since dehydration and roasting can reduce the amount of the antioxidant compounds present in foods.

Oxidative stress analysis by TBA performed at $0,30,6090$, and 120 days in the cereal bars made with fruit peels and baru with LWV, TWV, TV, and LV types of packaging under standard conditions showed no lipid oxidation since the color obtained after analysis during the storage period studied for the four treatments was green, indicating no reaction of malonaldehyde, a product of autoxidation of polyunsaturated fatty acids with TBA, forming the TBA-malonaldehyde complex of red color (OSAWA; FELICIO; GONÇALVES, 2005). After this period (120 days) of storage, the cereal bar exhibited lipid oxidation.

Borgo and Araújo (2005) reported that the susceptibility of fat to oxidation depends not only on its unsaturated fatty acids content and its nature, but also on its position in the lipid molecule. In addition, oxidation mechanisms in complex biological systems such as food, in which lipids are associated with the non-lipid compounds and have restricted mobility, may be quite different from those that occur in homogeneous phase.

According to Inoue, Shiota and Ito (1998), it is expected that the oxidation of lipids increases during storage and can be accelerated by increased temperature and conditions of low $\mathrm{pH}$. In the present study, it could be observed that both the treatment factor (type of packaging) as the time factor did not affect significantly $(\mathrm{p}<0.05)$ the variable oxidation up to 120 days of storage.

\subsection{Fatty acids profile}

The mean and standard deviation of the fatty acid profile of the cereal bars made with fruit peel and baru packaged in four different types of packaging are shown in Table 4.
Table 4. Fatty acid profile of the cereal bars made with fruit peels and baru nuts ${ }^{1}$.

\begin{tabular}{|c|c|}
\hline Fatty acids & g. $100 \mathrm{~g}^{-1}$ sample \\
\hline Lauric acid (C 12:0) & $0.10 \pm 0.01$ \\
\hline Miristic acid (C 14:0) & $0.26 \pm 0.0$ \\
\hline Palmitic acid (C 16:0) & $15.29 \pm 0.11$ \\
\hline Margaric acid (C 17:0) & $0.08 \pm 0.00$ \\
\hline Stearic acid (C 18:0) & $5.10 \pm 0.05$ \\
\hline Arachidonic acid (C 20:0) & $1.02 \pm 0.01$ \\
\hline Behenic acid (C 22:0) & $2.42 \pm 0.07$ \\
\hline Lignoceric acid (C 24:0) & $3.04 \pm 0.10$ \\
\hline Total saturated fatty acids $\left(\mathrm{g} \cdot 100 \mathrm{~g}^{-1}\right)$ & 27.31 \\
\hline Palmitoleic acid (C 16:1) & $0.10 \pm 0.00$ \\
\hline Oleic Acid (C18:1cis n9) & $44.66 \pm 0.12$ \\
\hline Vaccenic acid (C18:1cis 11$)$ & $0.58 \pm 0.01$ \\
\hline Linoleic acid (C18:2) & $24.50 \pm 0.09$ \\
\hline Gadoleic acid (C20:1) & $1.36 \pm 0.04$ \\
\hline Linolenic acid (C 18:3) & $0.56 \pm 0.02$ \\
\hline Erucic acid (C22:1) & $0.18 \pm 0.03$ \\
\hline Timnodonic acid (C20:5) & $0.06 \pm 0.01$ \\
\hline Clupanodonic acid (C22:5) & $0.26 \pm 0.02$ \\
\hline Total unsaturated fatty acids (g. $\left.100 \mathrm{~g}^{-1}\right)$ & 72.26 \\
\hline Unidentified fatty acids & $0.43 \pm 0.01$ \\
\hline Total fatty acids (g. $\left.100 \mathrm{~g}^{-1}\right)$ & 100 \\
\hline
\end{tabular}

${ }^{1}$ Correspond to mean values at $0\left(\mathrm{t}_{0}\right), 30\left(\mathrm{t}_{1}\right), 60\left(\mathrm{t}_{2}\right), 90\left(\mathrm{t}_{3}\right)$, and $120\left(\mathrm{t}_{4}\right)$ days of storage for the different types of packaging used; Values are expressed as mean \pm standard deviation.

The fatty acid profile of the cereal bars made with fruit peel and baru packaged in LWV, TWV, TV, and LV, was not significant $(\mathrm{p}<0.05)$ when evaluating the type of packaging and time alone and when evaluating the treatments at each specific time. These results can be explained by the fact that the samples did not undergo lipid oxidation, as previously described, by the TBA test during the 120 days of storage.

The fatty acid profile of the cereal bars made with fruit peel and baru showed high levels of monounsaturated and polyunsaturated fatty acids, $72.26 \mathrm{~g} .100 \mathrm{~g} \mathrm{~g}^{-1}$ with predominance of oleic and linoleic fatty acids due to the use of baru almond, which has $\omega$ 6: $\omega 3$ fatty acids at the ratio of 9:1, and is therefore beneficial to health since they can reduce the risk of developing cardiovascular disease (FREITAS; NAVES, 2010). The percentage of total saturated fatty acids was $27.31 \mathrm{~g} .100 \mathrm{~g}^{-1}$, especially palmitic, stearic, lignoceric, behenic, and arachidonic acids. 
Vera et al. (2009) characterized baru nuts and obtained oleic acid $(\omega 9)$ and linoleic acid $(\omega 6)$ as the most abundant fatty acids, followed by palmitic, lignoceric, stearic, behenic gadoleic, and araquitic acids, with average levels of saturated fatty acids ranging from 19.93 to 25.74 g. $100 \mathrm{~g} \mathrm{~g}^{-1} 1$ and unsaturated fatty acids from 73.47 to $79.19 \mathrm{~g} .100 \mathrm{~g}^{-1}$. Takemoto et al. (2001) found higher levels of unsaturated fatty acids $\left(81.20 \mathrm{~g} .100 \mathrm{~g}^{-1}\right)$ in Baru nuts, especially oleic (50.40 g. $100 \mathrm{~g} \mathrm{~g}^{-1}$ ) and linoleic acids (28.90 g. $\left.100 \mathrm{~g}^{-1}\right)$; the latter is considered an essential fatty acid.

Thus, it could be inferred that baru nuts added increased the lipid quality of the cereal bars investigated due to the presence of monounsaturated fatty acids such as oleic acid, which dows not affect the cholesterol levels, and to the polyunsaturated fatty acids such as linoleic acid, which reduces serum LDL cholesterol (TAKEMOTO et al., 2001).

\section{Conclusions}

Cereal bars made with fruit peels and baru can be an alternative for the use of waste from the food industry and sustainable use of fruits from the Brazilian savanna; can be the packaged in any of the following types of packaging PET/ polyethylene packaging (density of $100 \mathrm{~g} / \mathrm{m}^{2}$ ): laminated without vacuum (LWV), transparent without vacuum (TWV), transparent under vacuum (TV), and laminated under vacuum (LV) without any influence on the proximate composition, fatty acid profile, and lipid oxidation for a period of 120 days. However, further studies should be conducted to verify whether the product maintains sensory stability under the conditions evaluated.

\section{Acknowledgements}

The authors acknowledge the financial supported provided by CNPq.

\section{References}

ASSOCIATION OF OFFICIAL ANALYTICAL CHEMISTS - AOAC INTERNATIONAL. Official methods of analysis of AOAC International. 16th ed. Gaitherburg: AOAC International, 1997. $1850 \mathrm{p}$.

BLIGH, E. G.; DYER, W. J. A rapid method of total lipid extraction and purification. Canadian Journal of Biochemistry and Physiology, v. 37, p. 911, 1959. PMid:13671378. http://dx.doi.org/10.1139/ 059-099

BORGO, L. A.; ARAÚJO, W. M. C. Mecanismos dos processos de oxidação lipídica. Revista Higiene Alimentar, v. 19, n. 130, p. 5058, 2005.

BORGUINI, R. G. Avaliação do potencial antioxidante e de algumas características físico-químicas do tomate (Lycopersicon esculentum) orgânico em comparação ao convencional. 2006. 178 f. Tese (Doutorado em Saúde Pública)-Faculdade de Saúde Pública, Universidade de São Paulo, São Paulo, 2006.

BRAND-WILLIAMS, W.; CUVELIER, M. E.; BERSET, C. Use of a free radical method to evaluate antioxidant activity. LWT - Food Science and Technolology, v. 28, n. 1, p. 25-30, 1995.

BRASIL. Resolução RDC n 360, de 23 de dezembro de 2003. Regulamento Técnico sobre Rotulagem Nutricional de Alimentos
Embalados, tornando obrigatória a rotulagem nutricional. Diário Oficial da República Federativa do Brasil, Brasília, DF, 22 dez. 2003. Seção 1, n. 251.

CARVALHO, M. G. Barras de cereais com amêndoas de chichá, sapucaia e castanha-do-gurguéia, complementadas com casca de abacaxi. 2008. 92 f. Dissertação (Mestrado em Tecnologia de Alimentos)-Universidade Federal do Ceará, Fortaleza, 2008.

CECCHI, H. M. Fundamentos teóricos e práticos de análise de alimentos. 2. ed. Campinas: Unicamp, 2003.

CHAIYASIT, W. et al. Role of physical structures in bulk oils on lipid oxidation. Critical Reviews in Food Science and Nutrition, v. 47, p. 299-317, 2007. PMid:17453926. http://dx.doi. org/10.1080/10408390600754248

DECKER, E. A.; XU, Z. Minimizing rancidity in muscle foods. Food Tecnology, v. 52, n. 10, p. 54-59, 1999.

DE PAIVA, A. P. Estudos tecnológico, químico, físico-químico e sensorial de barras alimentícias elaboradas com subprodutos e resíduos agroindustriais. 2008. 131 f. Dissertação (Mestrado em Ciência dos Alimentos)-Universidade Federal de Lavras, Lavras, 2008.

FALLER, A. L. K.; FIALHO, E. Polyphenol content and antioxidant capacity in organic and conventional plant foods. Journal of Food Composition and Analysis, n. 23, p. 561-568, 2010. http://dx.doi. org/10.1016/j.jfca.2010.01.003

FERNANDES, D. C. et al. Nutritional composition and protein value of the baru (Dipteryx alata Vog.) almond from the Brazilian Savanna. Journal of the Science of Food and Agriculture, v. 90, n. 10, p. 1650-1655, 2010. PMid:20564449. http://dx.doi.org/10.1002/ jsfa.3997

FERREIRA, D. F. Análises estatísticas por meio do Sisvar para Windows 4. 0. In: REUNIÃO ANUAL DA REGIÃO BRASILEIRA DA SOCIEDADE INTERNACIONAL DE BIOMETRIA, 45., São Carlos, 2000. Anais... São Carlos, Universidade Federal de São Carlos, 2000. p. 255-258.

FOOD AND AGRICULTURAL ORGANIZATION OF THE UNITED NATIONS - FAO. Food energy - methods of analysis and conversion factors. Rome: FAO, 2003. Food and Nutrition Paper 77. Disponível em: <ftp://ftp.fao.org/docrep/fao/006/y5022e/y5022e00. pdf $>$. Acesso em: 03 mar. 2010.

FREITAS, D. G. C.; MORETTI, R. H. Barra de cereais de elevado teor protéico e vitamínico: estabilidade enzimática e das vitaminas $\mathrm{C}$ e $\mathrm{E}$ durante armazenamento. Archivos Latinoamericanos de Nutricón, v. 56, n. 3, 2006. PMid:17249488.

FREITAS D. G. C.; MORETTI, R. H. Caracterização e avaliação sensorial de barra de cereais funcional de alto teor protéico e vitamínico. Ciência e Tecnologia de Alimentos, v. 26, n. 2, p. 318324, 2005. http://dx.doi.org/10.1590/S0101-20612006000200014

FREITAS, J. B.; NAVES, M. M. V. Composição química de nozes e sementes comestíveis e sua relação com a nutrição e saúde. Revista de Nutrição, v. 23, n. 2, p. 269-279, 2010. http://dx.doi.org/10.1590/ S1415-52732010000200010

GUIMARÃES, M. M.; SILVA, M. S. Qualidade nutricional e aceitabilidade de barras de cereais adicionadas de frutos de muricipassa. Revista do Instituto Adolfo Lutz, v. 68, n. 3, p. 426-433, 2009.

GUTKOSKI, L. C. et al. Desenvolvimento de barras de cereais à base de aveia com alto teor de fibras. Ciência e Tecnologia de Alimentos, v. 27 , n. 2, p. 355-363, 2007. http://dx.doi.org/10.1590/S010120612007000200025

GRDEN, L; OLIVEIRA, C. S.; BORTOLOZO, E. A. F. Q. Elaboração de uma barra de cereal como alimento compensador para praticantes 
de atividades físicas e atletas. Revista Brasileira de Tecnologia Agroindustrial, v. 2, n. 1, p. 87-94, 2008. http://dx.doi.org/10.3895/ S1981-36862008000100008

INOUE, K.; SHIOTA, K.; ITO, T. Preparation and properties of ice cream type frozen yogurt. International Journal of Dairy Technology, v. 51, p. 44-51, 1998. http://dx.doi.org/10.1111/j.1471-0307.1998. tb02506.x

JOSEPH, J. D.; ACKMAN, R. G. Capillary column gas chromatography method for analysis of eneapsulated fish oil and fish oil ethyl esters: collaborative study. Journal of AOAC International, v. 75, p. 788506, 1992.

LIMA, J. C. R. et al. Qualidade microbiológica, aceitabilidade e valor nutricional de barras de cereais formuladas com polpa e amêndoa de baru. Boletim CEPPA, v. 28, n. 2, 2010.

MOURE, A. et al. Natural antioxidants from residual sources. Food Chemistry, v. 72, p. 145-171, 2001. http://dx.doi.org/10.1016/ S0308-8146(00)00223-5

NOGUEIRA, A. et al. Efeito do processamento no teor de compostos fenólicos em suco de maçã. Publicatio UEPG, v. 9, n. 3, p. 7-14, 2003.

OSAWA, C. C.; FELÍCIO, P. E.; GONÇALVES, L. A. G. Teste de TBA aplicado a carnes e derivados: métodos tradicionais, modificados e alternativos. Química Nova, v. 28, n. 4, p. 655- 663, 2005. http:// dx.doi.org/10.1590/S0100-40422005000400019

ROESLER, R. et al. Atividade antioxidante de frutas do cerrado. Ciência e Tecnologia de Alimentos, v. 27, n. 1, p. 53-60, 2007. http://dx.doi. org/10.1590/S0101-20612007000100010
SAMPAIO, C. R. P.; FERREIRA, S. M. R.; CANNIATTI-BRAZACA, S. G. Physico-chemical and nutritional characterization of cereal bars fortifi ed with iron. Alimentos e Nutrição, v. 21, n. 4, p. 607616, 2010.

SCHIEBER, A.; STINTZING, F. C.; CARLE, R. By-products of plant food processing as a source of functional compounds - recent developments. Trends in Food Science \& Technology, v. 12, p. 401-413, 2001. http://dx.doi.org/10.1016/S0924-2244(02)00012-2

SILVA, I. Q. et al. Obtenção de barra de cereais adicionada do resíduo industrial de maracujá. Alimentos e Nutrição, v. 20, n. 2, p. 321329, 2009.

TARLADGIS, B. G.; PEARSON, A. M.; JUN, L. R. D. Chemistry of the 2-tiobarbituric acid test for determination of oxidative rancidity in foods. Journal Science Food Agricultury Champaing, v. 15, p. 602607, 1964. http://dx.doi.org/10.1002/jsfa.2740150904

TAKEMOTO, E. et al. Composição química da semente e do óleo de baru (Dipterix alata Vog.) nativo do Município de Pirenópolis, Estado de Goiás. Revista do Instituto Adolfo Lutz, v. 60, n. 2, p. 113-117, 2001.

VERA, R. et al. Características químicas de amêndoas de barueiros (Dipteryx alata Vog) de ocorrência natural no cerrado do estado de Goiás. Revista Brasileira de Fruticultura, v. 31, n. 1, p. 112-118, 2009. http://dx.doi.org/10.1590/S0100-29452009000100017

WOLFE, K.; WU, X.; LIU, R. H. Antioxidant Activity of Apple Peels. Journal of Agricultural and Food Chemistry, v. 51, n. 3, 2003. http://dx.doi.org/10.1021/jf020782a 